Оксана Микитюк

ORCID: orcid.org/0000-0003-3922-4610

DOI 10.31558/1815-3070.2021.41.30

УДК 821.161.2.091

\title{
ПЕРСОНОМЕН ШЕВЧЕНКО ЯК МАРКЕР БІНАРНИХ ОПОЗИЦІЙ У ТВОРАХ ДМИТРА ДОНЦОВА
}

Проаналізовано персономен Шевченко, щуо є ідеологічним маркером індивідуальноавторської картини світу Д. Дониова. Встановлено, що базова сема 'героїчне козаџьке минуле' є наскрізною для бінарних опозицій персономена Шевченко та персономенів Куліш, Драгоманов, Рильський, Федькович. Виявлено, щуо в публіцистиці мислителя персономен Шевченко має лише позитивну конотацію, а персономени Куліш (XIX cm.), Рильський (ХХ ст.) та ін. в діахронії формують негативну конотацію. 3'ясовано, щзо персонімікон творів Д. Донцьова відтворює суспільно-політичне та культурно- історичне тло епохи.

Ключові слова: бінарна опозииія, індивідуально-авторська картина світу, персономен Шевченко, персонімікон творів, Д. Донџов.

Постановка наукової проблеми та її актуальність. Важливою складовою сучасних мовних досліджень $є$ їхній міждисциплінарний характер, що дозволяє усвідомити арсенали слововживань та світобачення автора, актуалізувати через мовні засоби тогочасну суспільнополітичну ситуацію та відтворити мовну картину світу.

Особливе місце в комунікації зі світом є вивчення мовної особистости Д. Донцова. Публіцистика ідеолога українського націоналізму не була предметом мовознавчого вивчення, попри те, що ці тексти знані в царині філософії, політології, історії, літературознавства. У творах мислителя персономен Шевченко творить своєрідну мікросистему, є часто вживаним повторювальним елементом, відтак концентрує та актуалізує увагу читача. Важливо, що спадщина Д. Донцова $є$ фокусом прийняття ідей Кобзаря та чинником формування державотвірного світогляду.

Аналіз досліджень цісї проблеми. Дослідження поданої теми базовано на вивченні мовної постаті Д. Донцова, яке має опертям дані лінгвоперсонології (Загнітко 2017; Космеда 2012; Фаріон 2012), зокрема, і в дидактичному аспекті (Мацько 2013); лінгвістики тексту, яка оперує функціюванням слова в системі певного твору, моделює мовноособистісні текстові корпуси (Сщенко 2009; Кочан 2008); когнітивної лінгвістики, що розкриває мову крізь мовленнєві процеси та елементи пізнавальної діяльности людини (Біскуб 2018; Нестерова 2015); етнолінгвістики, що об'єднує мову, культуру, етнографію, ментальність, свідомість в єдине ціле (Барилова 2011; Голубовська 2004; Жайворонок 2005); лінгвокомунікації, що артикулює визначальні субконцепти (Супрун 2015) тощо. Окремо варто відзначити наявні дослідження творів Д. Донцова, зокрема, рецепцію концепту «слово» здійснила I. Фаріон (Фаріон 2012), а лінгвоперсона публіциста є предметом роботи О. Микитюк (Микитюк 2018).

Аналіз мовної особистости крізь перетин мовознавчих дисциплін дає змогу зрозуміти націєтвірні ідеї Т. Шевченка, мовно-політичну ситуацію того часу та екстраполювати досліджуване на сучасну мовну ситуацію. Дотичними до вивчення запропонованої міждисциплінарної теми є праці різних гуманітарних дисциплін. Наприклад, в історикополітичному аспекті охарактеризовано українську національно-визвольну традицію, що має своїм опертям твори Д. Донцова (Квіт 2013); в літературознавчо-публіцистичному плані переконливо виокремлено концепцію мислителя, що сформована на ідеях духовости, національних традицій, гартуванні героїчного, плеканні культу чести та шляхетности (Баган 2008). Прикметно, що навіть протиставлення поглядів Д. Донцова (як пропагатора Шевченкових ідей) та М. Драгоманова є окремим предметом розгляду (Ковальчук 2010; Лісовий 1996; Супрун 2015).

(C) Микитюк О., 2021 
Актуальність дослідження вмотивовує потреба створити мовний портрет Д. Донцова.

Мета і завдання. Мета: проаналізувати вживання персономена Шевченко як основу бінарних опозицій у творах Д. Донцова.

Відповідно до поставленої мети завданням статті є:

- відтворити мовну особистість Д. Донцова на основі розуміння Шевченкових постулатів;

- подати розуміння донцовського світогляду крізь персономени;

- виявити семне навантаження бінарних опозицій як маркерів публіцистики мислителя;

- визначити конотацію опозицій в Д. Донцова;

- простежити діахронію персонімікону творів;

- на основі джерельного матеріалу відтворити суспільне, історичне та культурне тло епохи.

Об’скт і предмет дослідження. Об’єктом роботи є публіцистика Д. Донцова. Предмет аналізу - персономен Шевченко, який формує бінарні опозиції в творах мислителя, а вибір дослідження стосується лінгвокультурної персонології, яка визначає значущість «тих чи тих лінгвокультурних кодів в еволюції мовної особистості» (Загнітко 2017: 5).

Опис фактичного матеріалу та методів, застосованих у процесі аналізу. До мовного аналізу залучено 10-томове видання творів Д. Донцова (Донцов Д. Вибрані твори: в 10 т. - далі ДДВТ), де на основі суцільної вибірки простежено вживання персономена Шевченко.

У роботі використано описовий метод, що дозволяє охарактеризувати функціювання персономена в системі публіцистичних творів Д. Донцова; метод інформаційно-смислового аналізу, котрий акумулює в собі відомості про світ з погляду автора; метод контекстуального аналізу, метою якого є відтворити ідіостиль публіциста; метод спостереження як базу для формування ідейної позиції читачів; зіставний метод, відповідно до якого можна порівняти відомості про різні постаті.

Наукова новизна Новизною $є$ те, що крізь канву текстів вперше проілюстровано бінарні опозиції до персономена Шевченко, охарактеризовано мовотворчість та основну аргументаційну базу слововжитку Д. Донцова.

Теоретична і практична цінність отриманих результатів. Теоретичне значення полягає в тому, що показано вживання персономена Шевченко як основного маркувального матеріалу поглядів Д. Донцова, описано значеннєве навантаження бінарних опозицій, виокремлено індивідуальні прийоми добору лексики в поданій темі.

Практичне значення роботи важливе для формування словника мови Д. Донцова, вивчення стилістики мови, підготовки довідників про мову української публіцистики, читання теоретичних курсів з історичної соціолінгвістики. Також джерельна база може слугувати матеріалом для створення антології про мовну картину світу письменників міжвоєнного часу та формування корпусу текстів української публіцистики.

Виклад основного матеріалу й обгрунтування результатів дослідження. Лексикосемантичні особливості публіцистичного тексту $є$ тлом для відтворення суспільнополітичного часу та інформаційним збудником для читача. Відтак енциклопедичні знання, емоційний стиль письма, грунтовні характеристики зображуваного - це все становить суть мовного стилю Д. Донцова. Основним аргументаційним мовним засобом творів публіциста $є$ протиставлення, які він у своїх працях називає антитезою (ДДВТ 8: 270) та антагонізмом (ДДВТ 8: 52). І. Франко таку стилістичну фігуру означує контрастом, який рухає нашою уявою «від звичайних до незвичайних асоціацій, він осягає один з наймогутніших способів поетичного малювання» (Франко 1981: 67). Оскільки мова йде про певні персони та відтворення їхніх ідей у творах Д. Донцова, то використовуємо термін бінарні опозиції (також бінарні протиставлення, опозитивні відношення, опозитивні персономени, полярні опозитиви чи опозитиви).

Широко репрезентованим у публіцистиці є персономен Шевченко як база відтворення поглядів Д. Донцова. Важливо, що саме ідеологічні вказівки «Кобзаря» мислитель взяв за основу формування світогляду боротьби та вірности своїм ідеям. Персономен Шевченко є 
ключем для розуміння національно-культурного життя, відтворює конотативні судження Д. Донцова, які репрезентуються у свідомості читача.

Звертаючи увагу на соціолінгвальну ситуацію XIX віку з традиціями лібералізму, демократизму, гуманізму та гуманности, Д. Донцов вимальовує постать Т. Шевченка як такого, що завжди в дії, йому важливо, «аби не колодою гнилою валятися» (ДДВТ 7: 241); це тип людини творця, що вірить в українські традиції, у себе та в справедливого Бога. Мислитель бачить невідомого для інших «апокаліптичного Кобзаря» (ДДВТ 8: 156), «великого в'язня Росії» (ДДВТ 6: 83), боротьба якого постійна, бо навіть на засланні він зберігав вірність обраному шляхові, тому казав: «Караюсь, мучуся, але не каюсь!». Лексема Шевченко, вжита як маркувальний елемент мовної картини світу Д. Донцова, творить персономен його творів.

Бінарною опозицією до персономена Шевченко великий публіцист вибирає персономени, що репрезентують культурно-політичне тло різних історичних періодів, зокрема, П. Куліша - це XIX ст. (сучасник Т. Шевченка), М. Драгоманова, Ю. Федьковича - це кінець XIX ст. та М. Рильського - це XX ст.

\section{Персономени Шевченко - Куліш}

Логічним є зіставлення сучасників Т. Шевченка та П. Куліша, які в текстах Д. Донцова базовано на засадничому, непримиренному, всуціль антагоністичному конфлікті між цими реальними постатями. Формування бінарної опозиції персономенів Шевченко - Куліш стосується передусім семи 'минуле'. В українського Пророка - це «заглянути у вічі нашій славній i трагічній минувшині, iї твердому заповітові», протилежно подано позицію П. Куліша: «культуру темній Україні принесла щойно Москва і Петербург», також: «козацтво - хижацтво...» (ДДВТ 8: 55). Подані опозитивні відношення в творах Д. Донцова не $\epsilon$ несподіваними, вони утворені на основі вивчення численних матеріалів про письменників, тому $€$ не лише аргументаційним елементом твору, а й психоемоційним чинником переконання читачів у правильності авторської думки. Наступна опозиція персономенів має таку характеристику: «Шевченко стояв обома ногами у великій минувшині України, а братчики з Кулішем - у напів змосковщеній Малоросії, як би тепер сказали, в «реальній, сучасній» Україні» (ДДВТ 8: 56). Національна свідомість Д. Донцова однозвучна 3 переконаннями Є. Маланюка, який виокремлює козацький дух Кобзаря: «I незаперечним фактом у поезії Шевченка є iї виразно козацький дух, а найулюбленіші слово і образ: “слава”, “козацька слава” (як і “козацька кров”)» (Маланюк 2012: 58).

Емоційні судження Д. Донцова виразно оцінні, чітко йде протиставлення лексем з позитивною та негативною конотацією, приміром, козацтво (як позитив) чи хижацтво (як негатив). Доречно зазначити, що такий тип висловлювання В. Карасик називає когнітивною інформацією, тобто такою, що «співвідноситься зі змістом висловлювання, їі традиційно вивчає семантика» (Карасик 1989: 3).

Увагу читача актуалізовано і на опозиції щодо вдачі сучасників. Для персономена Шевченко стрижневу рису описано як «“нетолерантність” у відстоюванню своїх переконань» (ДДВТ 8: 56). Антиподом в тексті є персономен Куліш, якого визначено сентиментальним і експансивним егоцентриком, бо «не без підстав оцінювали його царські жандарми як “людину спокійну"» (ДДВТ 8: 56). Можна змоделювати бінарну опозицію на основі сем 'нетолерантність' - 'толерантність', тобто: нетолерантність Т. Шевченка, яка виявляється в обстоюванні власних інтересів та, по інший бік, начебто толерантність П. Куліша, що полягає в угодовстві, захопленням владою, бажанні не брати участи в жодній політичній царині, бути осторонь від усього, що потім Д. Донцов подаватиме як замилування рідним хутором.

За текстами мислителя бінарну опозицію (персономени Шевченко - Куліш) формують такі тлумачення: «переходив свою страшну хресну путь» - «здобував собі ласку задобрених його покорою царських слуг»; «“карався, мучився, але не каявсь”» - «покаявся і повернувся до життя»; «раз вибраної правди не кинув» - «плював у криницю, з якої замолоду пив живу воду»; «горів смолоскипом, світив світильником, у якім ніколи не бракувало олії, який світить і досі» - «зривався, злітав, падав, у похід збирався й заламувався» (ДДВТ 8: 60-61). Цей тип 
бінарних протиставлень, що відповідає семі ‘правда', особливо яскравий у тлумаченні Д. Донцова, бо він викривально подає всі слабкості П. Куліша, ідеї якого сформували основу для покоління пристосуванців, та Т. Шевченка, що став провісником великої правди та Пророком. У висліді, саме доля нації залежала від того, за ким піде наступне покоління.

Світоглядово промовистою є подача топоніма Петербург в Д. Донцова крізь призму опозитивів. Т. Шевченко, блукаючи над Невою, згадує «замучених козаків», «гетьмана Полуботка». Бінарне протиставлення формує світобачення П. Куліша, який патосно говорить про «“Петра творенье” - Петербург» (ДДВТ 8: 55) і бачить таке минуле, яке надихнуло О. Пушкіна на створення величної поеми.

Відмінним є і розуміння України в Т. Шевченка та П. Куліша. «Шевченко дивився на те “втихомирення” як на національну катастрофу, Куліш, навпаки, твердив, що доба героїки для України минулася, що “пора потрудитися ще й головою”, вести культурну, чисто аполітичну працю, бо ж “політичне життя України давно скінчено” (лист до Юзефовича)» (ДДВТ 8: 57). Найвагоміше місце у текстотворенні цього типу опозиції є думка Т. Шевченка про національне лихо, коли люди втрачають бажання боротися, та позиція П. Куліша про те, що доба героїки минула. Доречно нагадати про Революцію Гідности, про сучасну російсько-українську війну, оскільки саме звитяга та боротьба триває донині. Відтак топоніми Україна є стрижневим для відтворено політичної сутности минулого.

Інтелектуальний обшир Д. Донцова дозволяє зіставити мовний світогляд двох сучасників, яким відведено різне місце в українській історії. Домінанти, на основі яких створено бінарні опозиції персономенів Шевченко - Куліш, стосуються теми козацького минулого, політики (обстоювання власних інтересів), правди.

Персономен Куліш, уведений до численних творів Д. Донцова, відтворено як негативне сприйняття дійсности, натомість персономен Шевченко - це показ героїчного українського минулого, яке спроєктовано на утвердження державотвірних засад у майбутньому.

\section{Персономени Шевченко - Драгоманов}

Мислитель відзначає, що за життя М. Драгоманов не терпів Т. Шевченка за його духовність, за те, що Євангельські тексти ставали оновою його творів. Д. Донцов взаємини цих діячів влучно називає «Два антагоністи», а персономен Шевченко набуває стильової активности поруч з персономеном Драгоманов. Сема 'героїзм' є основною характеристикою обидвох постатей. Персономен Шевченко - це втілення героїки «як стимулу й ідеалу життя, <...> який сучасний світ поміркованости уважав світом недолюдків». Бінарним опозитивом є персономен Драгоманов, бо цей чоловік «не мав зрозуміння ні до героїзму, ні до гострої потреби поборювати власних недолюдків» (ДДВТ 4: 308).

Концептуальні ідеї Т. Шевченка цілковито втілив у націє- та державотрівну програму побудови самостійної України Д. Донцов. Суттєво, що про істотні світоглядові та мисленнєві розбіжності М. Драгоманова та Д. Донцова також методом бінарних опозицій пише В. Лісовий (приміром, драгоманівський раціоналізм, космополітизм та протилежним є донцовський ірраціоналізм, націоналізм тощо) (Лісовий 1997: 245-255). Інший дослідник - I. Ковальчук доводить, що погляди М. Драгоманова та Д. Донцова створювалися в різних історико-політичних та ідеологічних умовах, тому і призвели до «концептуально відмінних між собою положень» (Ковальчук 2010: 94).

Символічним є розуміння правди в Т. Шевченка та М. Драгоманова. Шевченкова правда «надхненна, вибухова, пристрасна, запалена однією негаснучою думкою, ненавидуча зло, 3 патріотизмом». Бінарною опозицією $є$ : «якраз за се не терпів його правди Драгоманов» (ДДВТ 8: 62). Біблія для Т. Шевченка - «невичерпне джерело надхнення»; протилежним є розуміння М. Драгоманова: «ся книга була “от лукавого”» (ДДВТ 8: 62). Ще одним джерелом захоплення Пророка була «Історія Русів», протилежною є позиція М. Драгоманова, бо «автора "Історії Русів” зве Драгоманов “туманом”, що лише запаморочує мозок» (ДДВТ 8: 63). Практично опозитивні відношення нанизані в межах однієї сторінки та стосуються таких сем: 'правда', 
'Біблія', ‘минуле', себто стрижневих елементів для формування світогляду та відтворення ідеологічної позиції Д. Донцова, яка співзвучна з Шевченковими максимами.

Прикметно, що надважливою характеристико Т. Шевченка є його духовість, про яку Л. Мацько зазначає: «Шевченко утверджував українськість власним буттям, самоідентифікацією, поетичним словом, сюжетами, малярством, прагнув оздоровлювати ситуацію світлом істини» (Мацько 2013: 180-181). Антипод М. Драгоманов був проти шевченківського фанатизму, не сприймав його всеохопної любови до рідного та ненавидів Т. Шевченка, бо він був воскресителем історичних традицій. Аби це пояснити, знову в тексті є бінарні опозитиви: Т. Шевченко втілював «велику епоху нашої старовини, блискучу, свіжу, таку чоловічу у порівнянні з миршавими “новими думками” соціялістичної драгоманівщини», а М. Драгоманов - «хирляву, згангреновану епоху демократизму й космополітизму» (ДДВТ 7: 233). Мислитель зазначає, що між цими епохами ціле провалля. Філософія Т. Шевченка - це «нема на світі України, немає другого Дніпра», тобто безумовна любов до свого, у М. Драгоманова «соціяльна справедливість» (ДДВТ 8: 63). Донцовське мовомислення невіддільне від аналізу історичної правди, аксіологічного виміру свого та чужого, бо все це становить основу його переконань.

Цілковите, як каже ідеолог українського націоналізму, противенство, було в атиподів Шевченка - Драгоманова щодо розуміння нації. «Для Шевченка нація, народ - се була певна духова цілість. Морально-розумова, психічна збірнота, але водночас найбільш дійсна, реальна річ на світі. Для Драгоманова таке поняття нації було фікцією» (ДДВТ 8: 66). Якщо виявити бінарні семи щодо розуміння нації, то ми отримаємо таку картину: нація - це 'духова цілість' (за Т. Шевченком) та 'нація як фікція' (за М. Драгомановим). Ці опозитиви в творах Д. Донцова відтворюють неприйнятність драгоманівського світовиміру та Шевченкову пророчість у висловлюванні.

Персономени Шевченко - Драгоманов підсилено розумінням іронії. Т. Шевченко, що успадкував дідову належність до козацького роду, вважав жартівливість своєю прикметою, бо козаки протиставляли веселість сумові, що був гріхом. Натомість для «дражливого» на сміх Драгоманова «"прикро”, як Шевченко “скаче од сліз жартів і цинізму”» (ДДВТ 8: 279). Висновок Д. Донцова: «Іронія - риса аристократична, тому мав їі Шевченко» (ДДВТ 8: 279). Сема 'іронія' стала смислотвірним елементом для відтворення способу життя цих людей.

Домінанти бінарних опозицій персономенів Шевченко - Драгоманов базовано на розумінні героїчного минулого, правди, свого та чужого, історичних традицій, нації та іронії. Мовна картина світу набуває грунтовної деталізації завдяки персономену Драгоманов, бо цей діяч переповнений цілим арсеналом ідей, які не сприймає Д. Донцов.

\section{Персономени Шевченко - Рильський}

Значимість мовно-ідейного наповнення літературних творів формують письменники Т. Шевченко та М. Рильський. У творах мислителя персономен Шевченко - це повага, трагізм й національна гордість. Опозицією до нього є персономен Рильський, у якого маємо «вибачення за те, що взагалі посмів перебирати струни української “наївної” ліри, коли довкола потужно гудуть єрихонські сурми Кремля» (ДДВТ 8: 110). Бінарно протиставленою в обидвох письменників є сема 'минуле'. По один бік персономен Шевченко, в якого «“нема кому порадоньки дати" народові якраз тому, що “козачество гине"», та по інший бік - персономен Рильський, який «“не має з ким іти по правду”, тому звертає очі до Москви» (ДДВТ 8: 113). Згідно з епохальним висновком Д. Донцова, Т. Шевченко чекає воскресіння козацького духу, натомість М. Рильський - це «поетичний лакей» (ДДВТ 8: 113).

Однозначно, що в обидвох письменників бінарну опозицію творить сема 'своє' та 'чуже'. Для Шевченка, який щойно переїздив кордон, то «вже чувся “на чужині”». Інше розуміння рідного в М. Рильського, бо «від Києва до Алтая - все се “наша Батьківщина”. А Москва? Се для "поета" вже - “моя Москва, мій Кремль, моє життя"» (ДДВТ 8: 114). Опозитивні відношення персономенів Шевченко - Рильський відтворено крізь палітру домінант, що стосуються 
національної гордости, героїчного минулого, розуміння свого та чужого, що у висліді є основою для позитивного чи негативного світосприйняття.

\section{Персономени Шевченко - Федькович}

Кількісно незначну групу становить опозиція персономенів Шевченко - Федькович, бо це зіставлення різної життєвої філософії. Бінарні протиставлення творять: «упоєння життям, хоч би грізним, гарне - се шал панувати, формувати життя» (у тексті це персономен Шевченко) та «гарне -“добре жити” і ні за чим “не тужити”» (персономен Федькович) (ДДВТ 8: 164). У результаті ще одна опозиція, що стосується розуміння життя: «велика туга сильної душі за сильним» (персономен Шевченко) та «велика втома малої душі за спокоєм» (персономен Федькович) (ДДВТ 8: 164). Ідея Ю. Федьковича «не тужити» (як і розуміння Кулішевого щастя на хуторі) ніяк не вписувалася в концепцію героїчного минулого українського народу, де понад усе цінувалася воля, яку потрібно було берегти від покоління до покоління. Тому слова Д. Донцова про традиції, козацтво, нехіть до відпочинку ніколи не знаходили відгомону в тих, які хотіли оспівувати безтурботне сьогодення попри невільне становище. Щасливе життя та героїчне минуле - це в Д. Донцова домінанти персономена Федькович.

Із стилістичною метою Д. Донцов наголошує на персономені Шевченко лише як на виразникові позитивного, тому епохальними є слова: «Серед розбурханого моря новочасного безбожницького нігілізму непорушною скелею стоїть Шевченків “Кобзар”» (ДДВТ 9: 323). Отже, Д. Донцов творить виразно бінарну мовну картину світу: по один бік стоїть персономен Шевченко, а по інший бік - персономени Куліш, Драгоманов, Рильський, Федькович, які численними прийомами актуалізації отримують негативну характеристику.

Висновки та перспективи дослідження. Публіцистика Д. Донцова є базою для вивчення історико-політичного часу, чинником концентрації уваги на визначальних подіях. Значеннєвий, емоційний, асоціативний план творів дає змогу відтворити позицію історичних постатей, що і формує особливість персонімікону великого публіциста.

Вивчення індивідуально-авторського стилю Д. Донцова доводить, що бінарні опозиції $є$ аргументаційним та текстотвірним елементом його публіцистики. Маркером творів $\epsilon$ персономен Шевченко, який має розлогий потенціал тлумачень, творить основу для розуміння донцовського світогляду, формує базові блоки з єдністю думок, слугує основою для визначення численних сем, які знаходять протиставлення в персономенах Куліш, Драгоманов, Рильський, Федькович.

Серед енциклопедично потужних та різнопланових (часово та територіально) персономенів творів Д. Донцова персономен Шевченко вирізняється частотністю цитувань, що дозволяє зробити висновок про ретельне знання творів Кобзаря, яким володіє мислитель. Постать Т. Шевченка для Д. Донцова - це культурно політичний орієнтир, тому автор оцінює інших письменників крізь призму Шевченкового світосприйняття, пророчости та геніальности.

Персономени, що творять опозитивні відношення до персономена Шевченко, набувають в тексті негативної конотації. Історичні традиції, розуміння минулого, бачення України - це все $є$ смисловими скріпами, на основі яких Д. Донцов будує власне розуміння постаті Пророка.

Цікавими є спільні семи, які формують бінарні опозиції на основі персонімікону творів. Персономен Шевченко в Д. Донцова творить бінарну опозицію з усіма проаналізованими персономенами (Куліш, Драгоманов, Рильський, Федькович) щодо семи 'героїчне козацьке минуле'. Персономени Драгоманов, Рильський утворили єдність у ставленні до свого та чужого. В опозиції до персономена Шевченко персономени Федькович та Куліш об’єднала сема 'щасливе життя', персономени Куліш та Драгоманов - сема 'правда'. Поодинокими для опозиції з персономеном Шевченко виявилися семи 'власні інтереси' (П. Куліш); 'традиція', ‘нація', ‘іронія’ (М. Драгоманов); 'національна гордість' (М. Рильський), які отримали конкретну вказівку на певний персономен.

Суцільна вибірка матеріалу показала, що персономени Шевченко - Драгоманов мають найбільшу кількість бінарних опозицій (іх шість) зі семами 'героїчне минуле', 'своє та чуже', 
'правда', ‘традиції', ‘нація', ‘іронія' і найменшу кількість опозицій (дві) виявлено в персономенів Шевченко - Федькович.

Персономени Куліш, Драгоманов, Федькович, Рильський, хоча належать до різного історичного періоду (від ХІХ до XX століття), є виразниками однозвучних ідей і творять бінарні протиставлення до позачасового виміру Шевченкового генія.

Матеріал дослідження дозволяє вивчити публіцистичні тексти крізь призму націє- та державотвірної функції мови. Персонімікон творів формує розуміння тогочасної епохи та отримує схвальний чи несхвальний відгук в ідеях Д. Донцова. Виражаючи національноспецифічне тло, персономени стають згустками ментального ставлення до світу, скеровують на розуміння ідеалу, вмотивовують цінності, тому і формують національно-мовну картину світу.

Перспективи подальших розвідок у цьому напрямі такі: а) сформувати словник мови Д. Донцова; б) простежити функцію персономенів у творенні мовної картини світу письменників-вісниківців.

\section{Література}

Баган, Олег Р. Поміж містикою і політикою (Дмитро Донцов на тлі української політичної історії першої половини ХХ ст.). Київ: УВС ім. Ю. Липи, 2008.

[Bahan, Oleh R. Pomizh mistykoyu i politykoyu (Dmytro Dontsov na tli ukrayins'koyi politychnoyi istoriyi pershoyi polovyny XX st.). Kyiv: UVS im. Yu. Lypy, 2008.]

Барилова, Галина К., Глуховцева, Катерина Д. Українська етнолінгвістика: навч. посіб. для студ. вищ. навч. закл. Луганськ: ЛНУ імені Тараса Шевченка, 2011.

[Barylova, Halyna K., Hlukhovtseva, Kateryna D. Ukrayins'ka etnolinhvistyka: navch. posib. dlya stud. vyshch. navch. zakl. Luhans'k: LNU imeni Tarasa Shevchenka, 2011.]

Біскуб, Ірина П. Філософія, суспільство, мова: монографія. Луцьк: Вежа-Друк, 2018.

[Biskub, Iryna P. Filosofiya, suspil'stvo, mova: monohrafiya. Luts'k: Vezha-Druk, 2018.]

Голубовська, Ірина О. Етнічні особливості мовних картин світу: монографія, 2-е вид., випр. і доп. Київ: Логос, 2004.

[Holubovs'ka, Iryna O. Etnichni osoblyvosti movnykh kartyn svitu: monohrafiya, 2-e vyd., vypr. i dop. Kyiv: Lohos, 2004.]

Єщенко, Тетяна А. Лінгвістичний аналіз тексту: навч. посіб. Київ: Академія, 2009.

[Yeshchenko, Tetyana A. Linhvistychnyy analiz tekstu: navch. posib. Kyiv: Akademiya, 2009.]

Жайворонок, Віталій В. Українська етнолінгвістика. Нариси. Київ: Довіра, 2007.

[Zhayvoronok, Vitaliy V. Ukrayins'ka etnolinhvistyka. Narysy. Kyiv: Dovira, 2007.]

Загнітко, Анатолій П. Теорія лінгвоперсонології: монографія. Вінниця: Нілан-Лтд, 2017.

[Zahnitko, Anatoliy P. Teoriya linhvopersonolohiyi: monohrafiya. Vinnytsya: Nilan-Ltd, 2017.]

Карасик, Владимир И. Статус лица в значении слова: Учебное пособие по спецкурсу. Волгоград: ВГПИ им. Серафимовича, 1989.

[Karasik, Vladimir I. Status litsa v znachenii slova: Uchebnoye posobiye po spetskursu. Volgograd: VGPI im. Serafimovicha, 1989.]

Квіт, Сергій М. Дмитро Донцов: ідеологічний портрет / Вид. 2-е, випр. і доп. Львів: Галицька видавнича спілка, 2013.

[Kvit, Serhiy M. Dmytro Dontsov: ideolohichnyy portret / Vyd. 2-e, vypr. i dop. Lviv: Halyts'ka vydavnycha spilka, 2013.]

Ковальчук, Іван В. «Михайло Драгоманов і Дмитро Донцов - антиподи української політичної думки». [В:] О. В. Потильчак (ред.) Актуальні проблеми вітчизняної та світової icmopiï: зб. наук. статей учасників Третіх Всеукраїнських драгоманівських чит. молодих істориків. Київ: Вид-во НПУ ім. М. П. Драгоманова. 2010, 86-95.

[Koval'chuk, Ivan V. «Mykhaylo Drahomanov i Dmytro Dontsov - antypody ukrayins'koyi politychnoyi dumky». [V:] O. V. Potyl'chak (red.) Aktual'ni problemy vitchyznyanoyi ta svitovoyi 
istoriyi: zb. nauk. statey uchasnykiv Tretikh Vseukrayins'kykh drahomanivs'kykh chyt. molodykh istorykiv. Kyiv: Vyd-vo NPU im. M. P. Drahomanova. 2010, 86-95.]

Космеда, Тетяна A. Ego i Alter Ego Tараса Шевченка в комунікативному просторі щоденникового дискурсу: монографія. Дрогобич: Коло, 2012.

[Kosmeda, Tetyana A. Ego i Alter Ego Tarasa Shevchenka v komunikatyvnomu prostori shchodennykovoho dyskursu: monohrafiya. Drohobych: Kolo, 2012.]

Кочан, Ірина М. Лінгвістичний аналіз тексту: навч. посіб. 2-е вид., перероб. і доп. Київ: Знання, 2008.

[Kochan, Iryna M. Linhvistychnyy analiz tekstu: navch. posib. 2-e vyd., pererob. i dop. Kyiv: Znannya, 2008.]

Лісовий, Василь С. Культура - ідеологія - політика. Київ: Видавництво імені Олени Теліги, 1997.

[Lisovyy, Vasyl' S. Kul'tura - ideolohiya - polityka. Kyiv: Vydavnytstvo imeni Oleny Telihy, 1997.]

Маланюк, Свген Ф. Нариси з історії нашої культури / С. Маланюк. Малоросійство. Нариси з історії нашої культури (уривки). Серія «Бронебійна публіцистика» / За заг. ред. Л. Івшиної. Вид. друге. Київ: ПрАТ «Українська прес-група», 2012.

[Malanyuk, Yevhen F. Narysy z istoriyi nashoyi kul'tury / Ye. Malanyuk. Malorosiystvo. Narysy z istoriyi nashoyi kul'tury (uryvky). Seriya «Bronebiyna publitsystyka» / Za zah. red. L. Ivshynoyi. Vyd. druhe. Kyiv: PrAT «Ukrayins'ka pres-hrupa», 2012.]

Мацько Любов I. «Мовна особистість Тараса Григоровича Шевченка як чинник формування українських філологів». [В:] С. К. Богдан (ред.) Волинь філологічна: текст $i$ контекст. Лінгвостилістика XXI століття: стан і перспективи: зб. наук. пр. / упоряд. С. К. Богдан. Луцьк: Східноєвроп. нац. ун-т ім. Лесі Українки, 2013. Вип. 15.

[Mats'ko Lyubov I. «Movna osobystist' Tarasa Hryhorovycha Shevchenka yak chynnyk formuvannya ukrayins'kykh filolohiv». [V:] S. K. Bohdan (red.) Volyn' filolohichna: tekst i kontekst. Linhvostylistyka KhKhI stolittya: stan i perspektyvy: zb. nauk. pr. / uporyad. S. K. Bohdan. Lutsk: Skhidnoyevrop. nats. un-t im. Lesi Ukrayinky, 2013. Vyp. 15.]

Микитюк, Оксана Р. «Антитеза як основа творчої манери Дмитра Донцова». [В:] І. Я. Павленко (ред.) Вісник Запорізького національного університету, Філологічні науки. Запоріжжя: Запорізький національний університет, № 2, 2018, 138-145.

[Mykytyuk, Oksana R. «Antyteza yak osnova tvorchoyi manery Dmytra Dontsova». [V:] I. Ya. Pavlenko (red.) Visnyk Zaporiz'koho natsional'noho universytetu, Filolohichni nauky. Zaporizhzhya: Zaporiz’kyy natsional'nyy universytet, № 2, 2018, 138-145.]

Нестерова, Марья Н. Когнитивистика: истоки, вызовы, перспективы: монография. Сумы: Университетская книга, 2015.

[Nesterova, Mar'ya N. Kognitivistika: istoki, vyzovy, perspektivy: monografiya. Sumy: Universitetskaya kniga, 2015.]

Супрун, Людмила В. «Кваліфікатив “національний” у контексті вісниківської публіцистики Д. Донцова». [В:] М.В.Мамич (ред.) Науковий вісник Міжнародного гуманітарного університету. Серія: Філологія. № 5. 2015, 158-161.

[Suprun, Lyudmyla V. «Kvalifikatyv “natsional'nyy” u konteksti visnykivs'koyi publitsystyky D. Dontsova». [V:] M. V. Mamych (red.) Naukovyy visnyk Mizhnarodnoho humanitarnoho universytetu. Seriya: Filolohiya. № 5. 2015, 158-161.]

Федурко, Марія Ю. «Онімний простір Шевченкового щоденника: інтелектуальний вимір». [В:] Л. М. Алексієвець (ред.) Наукові записки Тернопільського національного педагогічного університету. Серія: Мовознавство 1 (27). 2017, 304-308.

[Fedurko, Mariya Yu. «Onimnyy prostir Shevchenkovoho shchodennyka: intelektual'nyy vymir». [V:] L. M. Aleksiyevets' (red.) Naukovi zapysky Ternopil's 'koho natsional'noho pedahohichnoho universytetu. Seriya: Movoznavstvo 2017. 1 (27). 2017, 304-308.] 
Фаріон, Ірина Д. Шевченків концепт «слово» у рецепції Дмитра Донцова / Фаріон І. Слово меч духовний. Львів: Вид-во Львівської політехніки, 2012, 10-32.

[Farion, Iryna D. Shevchenkiv kontsept «slovo» u retseptsiyi Dmytra Dontsova / Farion I. Slovo mech dukhovnyy. Lviv: Vyd-vo L'vivs'koyi politekhniky, 2012, 10-32.]

Франко, Іван Я. Із секретів поетичної творчості. Зібр. тв.: у 50-ти т. Київ: Наукова думка. T. 31. 1981, 45-119.

[Franko, Ivan Ya. Iz sekretiv poetychnoyi tvorchosti. Zibr. tv.: u 50-ty t. Kyiv: Naukova dumka, T. 31. 1981, 45-119.]

\section{Використані джерела}

ДДВТ - Донцов Д. Вибрані твори: у 10 т. Т. 1-Т. 10 / Упоряд., післям., комент. О. Баган. Дрогобич : Відродження, 2011-2016.

\section{PERSONALIZATION (PERSONOMEN) SHEVCHENKO AS A LABEL OF BINARY OPPOSITIONS IN D. DONTSOV'S WORKS \\ Oksana Mykytyuk \\ Department of Ukrainian Language, Lviv Polytechnic National University, Lviv, Ukraine \\ Abstract}

Background: Systematization of linguistic, political science and literature data is an important step in the study of the D. Dontsov's linguistic portrait. Argumentative component in the texts furthers formation of an outlook.

Purpose: The purpose of the analysis is to determine the use of personomen Shevchenko as the basis of binary oppositions in the works of D. Dontsov.

Results: Personomen Shevchenko is a label of D. Dontsov's works. It has a wide potential for comparisons, interpretations and explanations and represents the basis of D. Dontsov's ideas. Although the personomens Kulish, Drahomanov, Fedkovych, and Rylsky belong to different historical periods (from the 19th to the 20th century), they express monosyllabic ideas and form a binary opposition to the timeless dimension of Shevchenko's genius.

The researched material allows to analyze journalistic text through the vision of nation-building and state-building function of language.

Discussion: The practical significance of the work is important for the formation of the dictionary of the language of D. Dontsov, for the preparation of reference books of Ukrainian journalism and for the study of the linguistic world picture of writers in the interwar period.

Prospects for further research are: a) to form a dictionary of D. Dontsov's language; b) to trace functions of proper names in the creation of linguistic world view of the writers of the journal "Visnyk".

Keywords: binary opposition, individualistic-authorial picture of the world, personomen Shevchenko, personymicon of the works, Dmytro Dontsov.

Vitae

Oksana Mykytyuk is Candidate of Philology, Associate Professor of the Ukrainian Language Department at the Lviv Polytechnic National University. Area of research interests includes speech culture, lexicology, applied linguistics, linguopersonology and terminology.

Correspondence: Oksana.R.Mykytiuk@lpnu.ua

Надійшла до редакції 18 березня 2021 року

Рекомендована до друку 1 квітня 2021 року 